\title{
Status, Use and Management of Urban Forests in Turkey
}

\section{Erdoğan Atmiş}

Bartın University, Faculty of Forest

Bartın

Turkey

eatmis@Bartın.edu.tr

\section{H. Batuhan Günşen}

Bartın University, Faculty of Forest, Bartın Turkey

\section{Abstract}

Background and purpose: From the 1950s onwards the urban population in Turkey has been increasing. Today, $77 \%$ of the population is living in cities and urban conglomerates. Public expectations from forest resources have changed, together with the migration of people from rural to urban centers. Due to rapid urbanization, the expectations from green areas and forests in and near cities have increased and changed for people living in the vicinity of cities. Following the world-wide trend in providing special attention to urban forests and to meet the demand and expectations from urban forests, the General Directorate of Forestry (OGM) has begun to deal with urban forestry from 2003 onwards. There are 112 urban forests in Turkey as of 2012. Out of these 72 are in provinces and the other 40 are in counties. The aim of the study is to determine general characteristics of urban forests in Turkey, to identify similarities and differences among the urban forests and to evaluate their appropriateness for the discipline of urban forestry.

Materials and methods: Studies were conducted from the beginning of May until the end of October 2010. This study was able to collect a sufficient amount of information for only 52 of the active urban forests. In total, 35 variables were derived by a literature study and interviews. Data was assembled from the Forest Regional Directorates through OGM. Frequency, minimum, maximum and mean values of the collected variables were calculated.

Results and conclusions: In conclusion, the analyses have focused on the general characteristics and accessibility of urban forests, urban forest infrastructure, urban forest management and urban forest services. Consequently, it was found that a standard was not reached for establishing urban forests in Turkey. Urban forests showed significant differences from each other in terms of various characteristics such as distance, accessibility, plant and animal diversity, water surfaces, facilities and infrastructure circumstances. Population and urbanization ratio were not considered in establishing and planning the related urban forests. Urban forests were mostly used for picnic and entertainment. Urban forests were not managed based on scientific and technical principles. Finally, some recommendations were presented to create a management infrastructure for urban forests in Turkey.

Keywords: administration, planning, recreation, urban forest, urban forestry, urbanization

Cengiz Yücedağ

Bartın University, Faculty of Engineering, Bartın, Turkey

\section{INTRODUCTION}

In developing countries urbanization has caused dramatic impacts by creating environments that lack amenities [1]. In this sense, since the 1950s onwards, the urban population in Turkey has begun to increase. Today, $77 \%$ of the population is living in cities and urban conglomerates. Public expectations from forest resources have changed together with the migration of people from rural to urban centers [2, 3]. Due to rapid urbanization, people's expectations from green areas and forests in and near cities have increased and changed.

Following the world-wide trend in providing special attention to urban forests and to meet the demand and expectations from urban forests, the General Directorate of Forestry (OGM) has started to show interest in urban forestry from 2003 onwards. There are 112 urban forests in Turkey as of 2012.72 out of them are in provinces and the other 40 are in counties. The total area of urban forests is 11230 ha [4]. Urban forests cover $0.01 \%$ of surface area and $0.05 \%$ of forest area in Turkey.

Urban forestry has been coined as the new face of forestry [5], as urbanization and increased availability of leisure time is increasing the importance of urban forests [6]. Its purpose is the cultivation and management of trees for their present and potential contribution to the physiological, sociological and economic well-being of the urban society $[7,8]$. Therefore, urban forests are integral components of the urban ecosystems [9]. Compared with other forests and nature areas, urban forests are thus real 'social forests', used by many local residents [10]. Most of the values attached to urban forests are non-priced environmental benefits. These values include those derived from pleasant landscapes, energy saving, clean air, peace and quietness, as well as potential recreational activities in wooded green spaces. Other benefits include a reduced wind velocity, noise prevention, balanced microclimate, shading, and erosion control $[2,11,12]$. 
Urban forestry in Turkey lacks a legal and administrative basis, due to the spontaneous and unplanned start of the OGM to work on urban forestry. In addition, central directives were launched all of a sudden to establish urban forests in all provinces. The problems that arose from poor planning, the random selection of urban forest locations and insufficient funding for attracting the right personnel have been observed by various authors. According to Coşkun and Velioğlu [13], urban forests remain mainly a concept and it is not part of the planning process and related legal regulations. The criteria for establishing urban forests are insufficient [14]. The basic needs and demands of those living in the city are not considered $[15,16]$. Moreover, uncertainties among authorities are in the way to resolve the debate among relevant institutions [17].

OGM recorded a number of existing plants and equipments in urban forests to amend their management. Moreover, open fire during picnics was banned in the "Picnic Spots Regulation" published in the Official Gazette dated 30 September 2006. But this has been far from enough to form the legal and administrative infrastructure for urban forests. In this Regulation, urban forest is defined as; "areas that are arranged in adjacent to or around settlements such as metropolis, provinces and big counties to present health, sport, aesthetic, cultural etc. social functions of forests to the public, but also to introduce technical forestry activities and flora and fauna in the district without traditional picnic understanding" [18].

The aim of this study is to determine the general characteristics of urban forests in Turkey, to identify similarities and differences among urban forests and to evaluate their appropriateness for the discipline of urban forestry. For this purpose, various variables were obtained and statistically analyzed. The analyses focused on the general characteristics and accessibility of urban forests, urban forest infrastructure, urban forest management and urban forest services.

\section{MATERIALS AND METHODS}

Studies were conducted from the beginning of May until the end of October 2010. Taking into account that some urban forests are inactive, whereas other urban forests have insufficient information, this study has been able to collect a sufficient amount of information for only 52 of the active urban forests.

A detailed literature study relating to urban forests was initially undertaken both at the national and the international level. Furthermore, to obtain quantitative information on urban forests in Turkey, we interviewed people from the forestry organization and representatives at the central and provincial level and examined related documents in the OGM archive in detail. A part of the data has been obtained in this way. Another part of the data was assembled from the Forest Regional Directorates through OGM. For this purpose, OGM sent a data collection form created by us to each of the 27 Forest Regional Directorates. The filled forms were returned to us afterwards.

As a result, in total 35 variables were derived from the literature study and interviews. The names and definitions of these variables are given in Table 1. Frequency, minimum, maximum and mean values of the derived

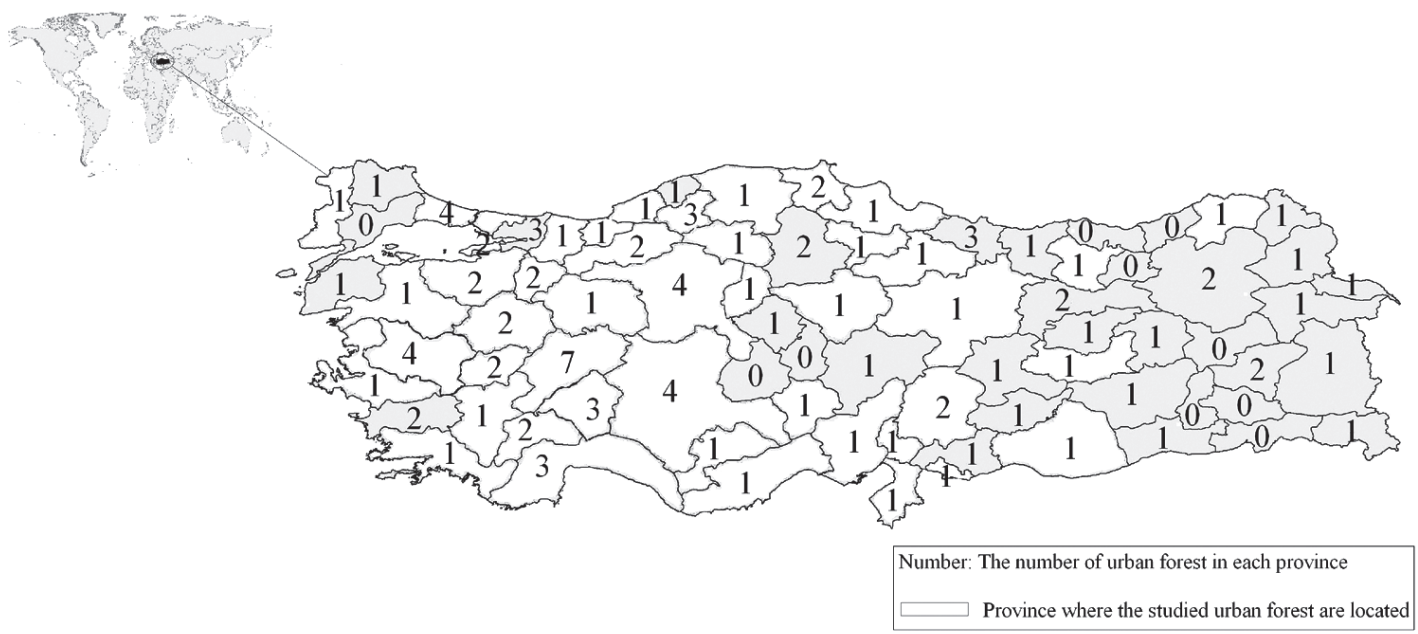


variables were calculated by using SPSS 16 (Statistical Package for the Social Sciences). The calculation results were evaluated under the following headings: general characteristics and accessibility of urban forests, urban forest infrastructure, urban forest management and urban forest services. These have been discussed based on the literature. In addition, the distribution of urban forests studied is presented in Figure 1.

\section{TABLE 1}

Names and definitions of variables

\begin{tabular}{|c|c|c|}
\hline No & Names of Variables & Definitions of Variables \\
\hline 1 & Activity period & Activity duration of urban forest \\
\hline 2 & Population of province-county & Urban population in province or county \\
\hline 3 & Distance & Distance between city center and urban forest \\
\hline 4 & The ratio of forest area & The ratio of forest area in province or county \\
\hline 5 & Urban forest area & Urban forest area \\
\hline 6 & Forest area per capita & Forest area per capita in province or county \\
\hline 7 & The number of picnic area & The number of picnic area in province or county \\
\hline 8 & Persons per picnic area & The Number of persons per picnic area in province or county \\
\hline 9 & Urbanization ratio & The Ratio of Urban population in province or county population \\
\hline 10 & The annual urban forest visitors & Visitor number of urban forest in a year \\
\hline 11 & Usage level & $\begin{array}{l}\text { The ratio of annual visitor number of urban forest in province or } \\
\text { county population }\end{array}$ \\
\hline 12 & The number of tree species & The number of tree species in an urban forest \\
\hline 13 & The number of coniferous tree $s p$ & The number of coniferous tree species in an urban forest \\
\hline 14 & The number of broad-leaved tree $\mathrm{sp}$ & The number of broad-leaved tree species in an urban forest \\
\hline 15 & The number of animal species & The number of animal species in an urban forest \\
\hline 16 & Urban forest area per capita & Urban forest area per person in province or county \\
\hline 17 & Sedile & The existence of sedile in an urban forest \\
\hline 18 & Viewpoint & The existence of viewpoint in an urban forest \\
\hline 19 & Fountain & The existence of fountain in an urban forest \\
\hline 20 & Sport Area & The existence of sport area in an urban forest \\
\hline 21 & Walking & The existence of walking path in an urban forest \\
\hline 22 & Playground & The existence of playground in an urban forest \\
\hline 23 & Toilet & The existence of toilet in an urban forest \\
\hline 24 & Parking area & The existence of parking area in an urban forest \\
\hline 25 & Bicycle road & The existence of bicycle road in an urban forest \\
\hline 26 & Information & The existence of information center in urban forest \\
\hline 27 & Province-county & The settlement where an urban forest is located \\
\hline 28 & Transportation possibilities & Transportation possibilities between city center and urban forest \\
\hline 29 & Water resources & The existence of water resources or surface in an urban forest \\
\hline 30 & Origin of urban forests & The situation of urban forest before its establishment \\
\hline 31 & Management plan & The existence of management plan for urban forest \\
\hline 32 & Urban forest management & Enterprise type of urban forest \\
\hline 33 & The number of personnel & The number of personnel in an urban forest \\
\hline 34 & The number of technical person & The number of technical personnel in an urban forest \\
\hline 35 & Functions of urban forest & $\begin{array}{l}\text { The functions of urban forest (recreation, sport activities, health } \\
\text { facilities, flora-fauna wealth etc) }\end{array}$ \\
\hline
\end{tabular}




\section{RESULTS AND DISCUSSIONS}

\section{General Characteristics and Accessibility of Urban Forests}

Eight of the studied urban forests are located in counties, whereas the other 44 are located in provinces. The population of the smallest and largest settlements (Isparta-Sütçüler and Istanbul) where urban forests were established are 12459 and 13 million, respectively (Table 2 ). In this context, Zhu and Zhang [19] claim that the urban forest area tends to increase with the number of urban population. As considered in this paper, the size of the settlements is very variable, but this variability has not been taken into consideration in planning urban forests. The size of settlements may essentially comprise different demands.

The minimum and maximum ratios of forest area in the studied provinces vary from $0.5 \%$ to $68 \%$, where-
In this study, the urbanization ratio (urban population/general population) is also calculated for settlements. The minimum and maximum urbanization ratio varies from $43 \%$ to $99 \%$ and its mean value is $68 \%$ (Table 2). It is well-known that people who are living in highly urbanized provinces/counties demand more recreational activities [22].

Out of 52 urban forests, the two newest ones are three years old, whereas the twelve oldest ones are eight years old. Besides, four urban forests are 5 years old, five of them are 6 years old and 29 of them are 7 years old. On average urban forests are 6.8 years old (Table 3).

The minimum and maximum distance within a province/county to urban forests varies between 1 to 40 $\mathrm{km}$, whereas the average distance is $7.9 \mathrm{~km}$. Distance is of great importance for visitors. Likewise, Hörnsten

TABLE 2

Characteristics for provinces/counties including urban forests

\begin{tabular}{|l|c|r|r|r|}
\cline { 2 - 5 } \multicolumn{1}{c|}{} & Unit & Min. & \multicolumn{1}{c|}{ Max. } & Mean \\
\hline Population of province-county & persons & 12459 & 13000000 & 700634 \\
\hline The ratio of forest area & $\%$ & 0.5 & 68 & 38 \\
\hline Forest area per capita & $\mathrm{m}^{2} /$ person & 0.01 & 36 & 4 \\
\hline The number of picnic area & number & 1 & 165 & 21 \\
\hline Persons per picnic area & persons & 655 & 698887 & 45616 \\
\hline Urbanization ratio & $\%$ & 43 & 99 & 68 \\
\hline
\end{tabular}

as the average ratio of forest area for 52 settlements is 38\% (Table 2). This also indicates that urban forests are established in both poor and rich cities as far as forest area are concerned.

The minimum and maximum forest area per capita varies from $0.01 \mathrm{~m}^{2}$ (Şanlıurfa Urban Forest) to $36 \mathrm{~m}^{2}$ (Kütahya- Domaniç Urban Forest), while the average forest area per capita is $4 \mathrm{~m}^{2}$ (Table 2). This is about half of the minimum green area per capita $\left(9 \mathrm{~m}^{2}\right)$ reported by World Health Organization $[20,21]$.

Urban forests in Turkey have met the needs of visitors for picnic areas. The minimum and maximum numbers of picnic area in settlements are 1 and 165, whereas the average is 21 (Table 2). Istanbul has 165 picnic areas, and this increases the mean value.

The minimum and maximum numbers of persons per picnic area are 655 and 698887 (Table 2), whereas its mean value is 45616 . Inclusion of the Istanbul province (or metropolitan) with a population of 13 million, with 78274 persons per picnic area has increased the mean value considerably.
TABLE 3

General characteristics of urban forest

\begin{tabular}{|l|c|r|r|r|}
\cline { 2 - 5 } \multicolumn{1}{c|}{} & Unit & Min. & Max. & Mean \\
\hline Activity period & years & 3 & 8 & 6.8 \\
\hline Distance & $\mathrm{km}$ & 1 & 40 & 7.9 \\
\hline Urban forest area & ha & 8 & 1025 & 144 \\
\hline
\end{tabular}

and Fredman [23] stated that over $40 \%$ of the population in Sweden would prefer urban forests which are within a distance of less than $1 \mathrm{~km}$ to settlements for recreational activities. The literature also shows that there is a negative relation between visitor frequency and distance $[24,25]$. According to studies done in 16 European countries, Konijnendijk [26] reported that urban forests were at a maximum distance of $50 \mathrm{~km}$ to city centers. On the other hand, Coles and Bussey [27] indicated that urban forests should ideally be at 5-10 minutes walk from the city centers. The attractiveness of forests as a recreational environment is also evident from the distance that people are willing to cover to visit a forest [28]. 


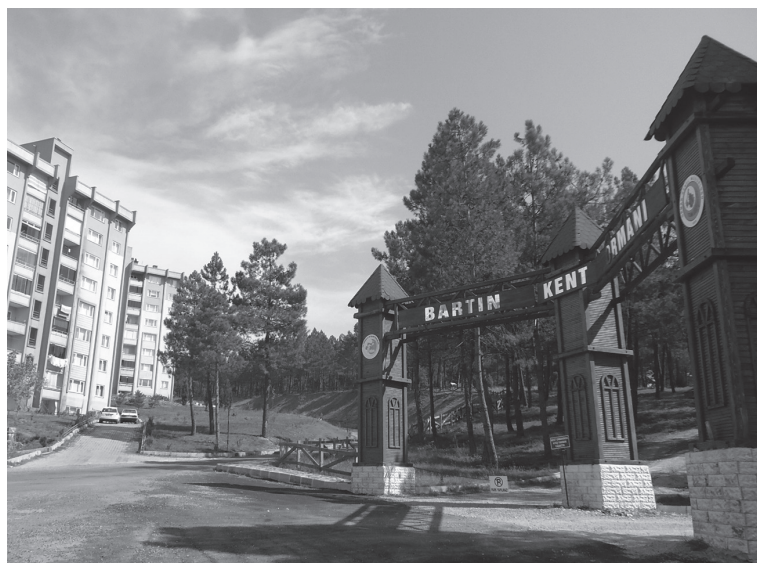

FIGURE 2

A view from Bartın Urban Forest

In Turkey, 28 (54\%) of the considered urban forests are within walking distance (Figure 2). They can be reached either by municipal buses (for 19 urban forests) and/or by small buses (for 21 urban forests). However, 11 urban forests cannot be reached either by walking or public transport. These urban forests can only be reached by private vehicles of the visitors. Furthermore, Uslu ve Ayaşlıgil [29] stressed the importance that urban forests should be reachable by either private or public transport.

The size of urban forests studied varies from 8 to $1025 \mathrm{ha}$, whereas the average is 144 ha. 34 out of 52 urban forests have smaller size than the mean value (Table 3). The large difference among the sizes of urban forests is due to the absence of standard sizes. In the Technical Prospectus for urban forests and resting areas, it is stated that the maximum area of urban forest should be 300 ha. In this case, only four out of 52 urban forests studied are larger than that value. In contrast, that prospectus does not mention the minimum limit for the size of urban forests. According to Gezer and Gül [12], the minimum size of urban forests

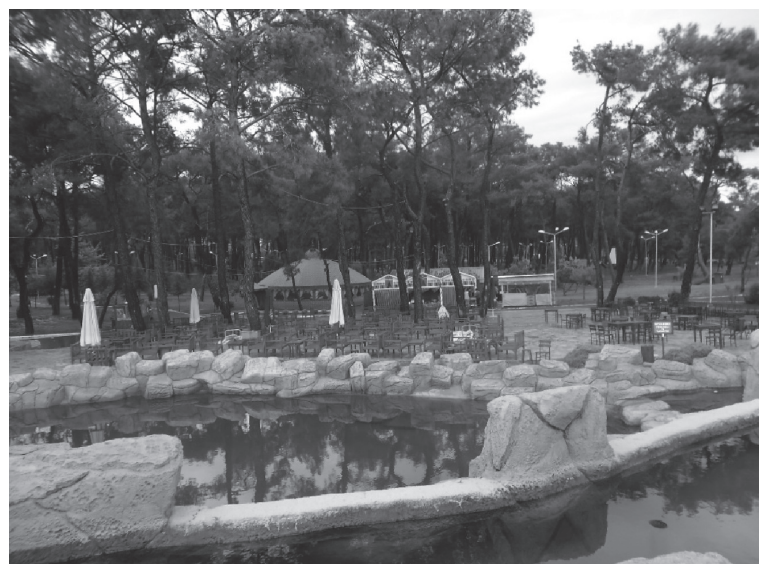

FIGURE 3

Artificial facilities in Kepez/Antalya Urban Forest

in Turkey should be 45 ha. This implies that 13 out of 52 urban forests are below the minimum size (Table 3 ).

\section{Urban Forest Infrastructure}

Forest visitors often prefer open green areas such as urban forests including various types of water resources [12]. Variation is greatly appreciated, not only due to mixtures with other types of trees, but also the combination of trees with fields, meadows and, in particular, water bodies [30]. In Turkey, only 22 urban forests (42.3\%) have a water resource such as a lake/pond, and stream (lake/ponds are found in 19 urban forests, streams are found in 2 urban forests, whereas both lake/ponds and streams are found in 1 urban forest). The other 30 urban forests include no water resource at all (Figure 3).

The origin of urban forests consists of $51.9 \%$ of afforestation (plantation) area, $36.5 \%$ of natural forest and $9.6 \%$ of picnic area (Figure 4). Most visitors appreciate the naturalness of an urban forest, and the importance of ecological management has increased during the past decade [31].

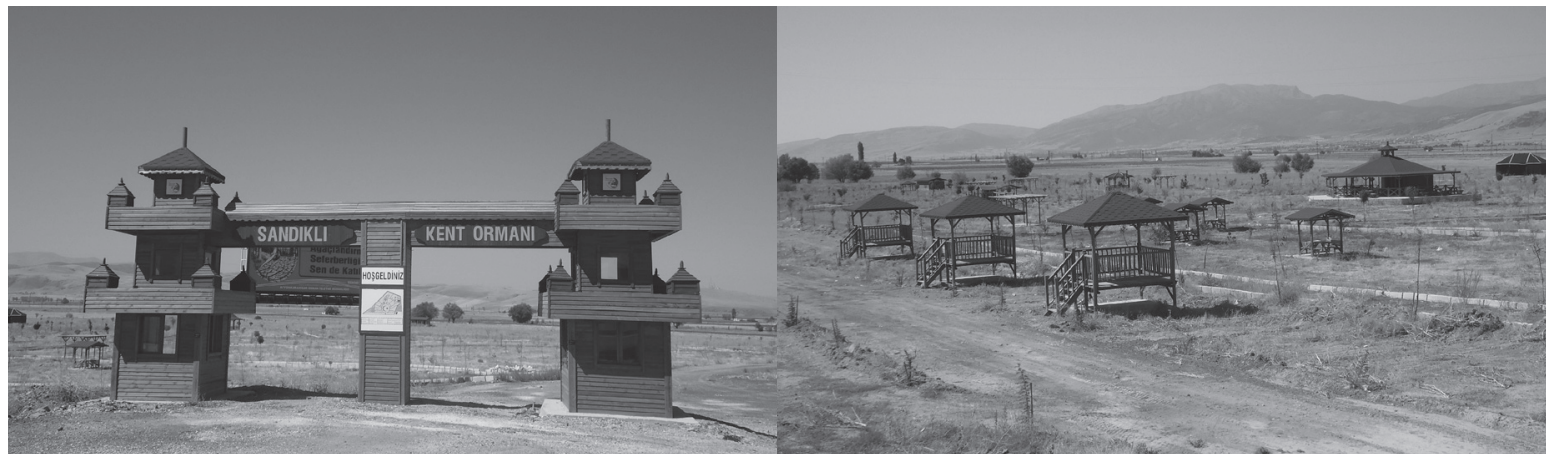

FIGURE 4

An urban forest in plantation area (Sandıklı/Afyon Urban Forest) 


\section{Urban Forest Management}

Currently only five urban forests $(9.6 \%)$ in Turkey have a management plan. Every urban forest virtually needs to have a management plan in order to provide a proper standard of urban forests services. Otherwise, urban forests may not develop in the desired direction. Çetiner et al. [32] stated that the municipality, forest management and the public have to participate to the administration to establish and manage an urban forest successfully and well. Therefore, there is a need for a proper management plan to be prepared by participation of interest groups.

Only 18 out of 52 urban forests are being managed by forestry organization. The rest of them have been managed by municipalities ( 29 urban forests), special provincial administrations (2 urban forests), private individuals ( 2 urban forests) and a village legal entity (1 urban forest). As understood from these results, forestry organizations prefer municipalities and the private sector to manage urban forests. However, municipalities and the private sector are often not able to manage the urban forest within the intended framework of the foundation purpose, because their main purpose is to gain income.

Some urban forests (9 urban forests) do not have even any personnel. The maximum number of personnel in an urban forest is 15, whereas the average is 4 . Furthermore, the number of technical personnel, such as forest engineers and landscape architects is quite low. 18 urban forests have no technical personnel at all. The mean number of technical personnel working in urban forests is as low as 1.44 .

\section{Urban Forest Services}

The number of tree species in urban forests of Turkey varies from 1 to 25 (Table 4). The Denizli Urban Forest consists of just one tree species only, while other urban forests have at least three different tree species. Two urban forests have no coniferous tree species, while six urban forests have no broadleaved tree species. Visitors often prefer urban forests with a higher diversity of tree species over natural forests with little variation $[33,34]$. Oğuz [15] pointed out that in Europe, urban forests with deciduous tree species are relatively more common and the tree age is variable. Dirik and Ata [35] and Gezer and Gül [12] also stressed that deciduous tree species have to be used for recreation areas. In this sense, it may be indicated that the attractiveness of urban forests will lessen with the decreasing of tree species diversity.

The minimum and maximum numbers of animal species in urban forests varies from 1 to 12 , and its mean value is only 5 (Table 4). The low number of animal species has resulted from the lack of animal inventory conducted in urban forests. Namely, the identification of animal species in urban forests has been done insufficiently. Actually, the real number is expected to be much higher.

\section{TABLE 4}

Information about urban forest composition

\begin{tabular}{|l|c|c|c|c|}
\cline { 2 - 5 } \multicolumn{1}{c|}{} & \multicolumn{1}{c|}{ Unit } & Min. & Max. & Mean \\
\hline $\begin{array}{l}\text { The number of } \\
\text { tree species }\end{array}$ & numbers & 1 & 25 & 8 \\
\hline $\begin{array}{l}\text { The number } \\
\text { of coniferous } \\
\text { tree sp. }\end{array}$ & numbers & 0 & 9 & 3 \\
\hline $\begin{array}{l}\text { The number of } \\
\text { broad-leaved } \\
\text { tree sp. }\end{array}$ & numbers & 0 & 16 & 5 \\
\hline $\begin{array}{l}\text { The number of } \\
\text { animal species }\end{array}$ & numbers & 1 & 12 & 5 \\
\hline
\end{tabular}

Annual average number of visitors per urban forest in Turkey is 25 603. Sinop Urban Forest has the lowest number (500) of annual visitors (Table 5). Here the public opinion is lacking any knowledge about the urban forest. The annual number of visitors in four other urban forests is below 1000 . On the other end of the scale, İstanbul Urban Forest has the highest number of visitors (about 200 000). The average number of visitors can be affected by different variables such as distance, location, personnel number, presence of a manager or management plan and the number of functions that the urban forest provides [36]. But in some urban forests of Turkey, the number of visitors is pretty low. The reason is that service units in those urban forests have not been completed and are not introduced sufficiently yet.

The usage level has been calculated as the ratio of the number of visitors to the urban population. According to Table 5, it varies from 1\% (in 14 urban forests) to $216.5 \%$ (Bilecik Urban Forest). Facilities such as casinos and wedding halls existing in Bilecik Urban Forest have increased the usage level of their urban forest considerably. Yet, these kinds of usages do not match the intended usage of urban forests. The average usage level of urban forests is $16.5 \%$ (Table 5 ).

Urban forest area per capita in some settlements is very low with $0.1 \mathrm{~m}^{2}$ (Ankara Urban Forest), which is as high as $106 \mathrm{~m}^{2}$ (Muğla Urban Forest) in other settlements. Its mean is $11 \mathrm{~m}^{2}$ in Turkey (Table 5). 


\section{TABLE 5}

Information about urban forest recreation services

\begin{tabular}{|l|c|c|c|c|}
\cline { 2 - 5 } \multicolumn{1}{c|}{} & Unit & Min. & Max. & Mean \\
\hline The annual urban forest visitors & persons & 500 & 200000 & 25603 \\
\hline Usage level & $\%$ & 1 & 216.5 & 16.5 \\
\hline Urban forest area per capita & $\mathrm{m}^{2} /$ person & 0.1 & 106 & 11 \\
\hline
\end{tabular}

In almost half of the urban forests, there are no car parking area lots and information centers. There are banks in 47 urban forests, viewpoints in 42, fountains in 40, and toilets in 37 (Table 6, Figure 5). Walking paths are the highest among the facilities presented in urban forests. There are walking paths in 49, sport areas in 34 and playgrounds in 45 urban forests (Table $6)$. In addition, there are no bicycle paths in the majority of the urban forests (94.2\%). Çetiner et al. [32] pointed out that parking area lots are important for urban forests to attract visitors.

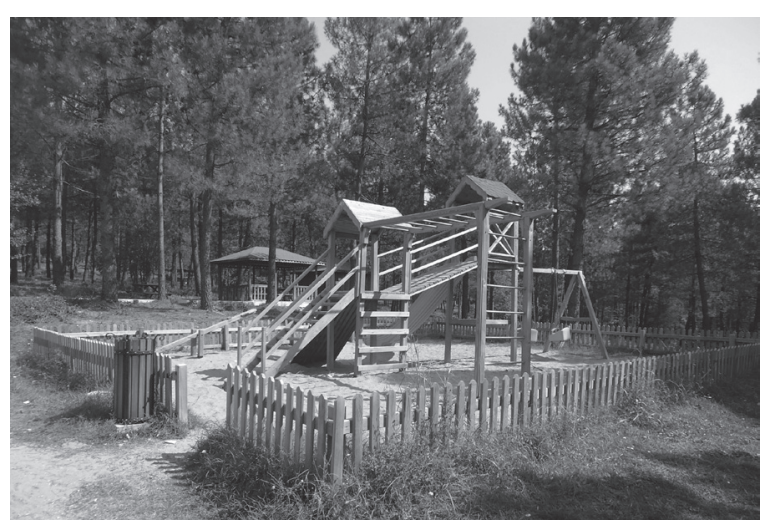

\section{FIGURE 5}

A Playground in Bartın Urban Forest
Recreation is important in $86 \%$ of the 52 urban forests in Turkey, various sport activities are possible in $75 \%$, health facilities exist in $60 \%$ and flora-fauna wealth is found in $31 \%$ of the urban forests. The main aim of urban forests is to provide services, such as carbon emission reduction, mitigation of air pollution, amelioration of the microclimate and the supply of recreation areas [9]. Only recreation and sport activities out of these aims are intensively utilized in urban forests of Turkey.

\section{CONCLUSIONS AND RECOMMENDATIONS}

Based on this study the following results can be reached. These are given below and focus on general characteristics and prominent deficiencies of urban forests in Turkey.

The experience with urban forests in Turkey is short, where on average urban forests existed for 6.8 years only. In this short time span the society did not get to know urban forests sufficiently well. Moreover, forestry organizations have not given much importance to urban forests too. Although more than 100 urban forests have been established in a short period of time, there have been insufficient efforts to improve the

\section{TABLE 6}

Actually recreational facilities in urban forests

\begin{tabular}{|l|c|c|c|c|}
\cline { 2 - 5 } \multicolumn{1}{c|}{} & \multicolumn{2}{c|}{ Frequency } & \multicolumn{2}{c|}{ Percent } \\
\cline { 2 - 5 } \multicolumn{1}{c|}{} & Existent & Absent & Existent & Absent \\
\hline Sedile & 47 & 5 & 90.4 & 9.6 \\
\hline Viewpoint & 42 & 10 & 70.8 & 19.2 \\
\hline Fountain & 40 & 12 & 65.9 & 23.1 \\
\hline Sport area & 34 & 18 & 94.2 & 34.6 \\
\hline Walking & 49 & 3 & 86.5 & 5.8 \\
\hline Playground & 45 & 7 & 71.2 & 13.5 \\
\hline Toilet & 37 & 15 & 51.9 & 28.8 \\
\hline Parking area & 28 & 25 & 5.8 & 48.1 \\
\hline Bicycle road & 3 & 49 & 53.8 & 94.2 \\
\hline Information center & 28 & 24 & 46.2 \\
\hline
\end{tabular}


quality of the established urban forests. Nevertheless the experiences with urban forestry have to be shared at the national or international level. For this purpose, forestry organization should collaborate with municipalities and non-governmental organizations and also an urban forestry congress at the national or international level can be held. With these efforts, not only the conceptual framework of urban forests can be evaluated, but also a model for urban forests in Turkey can be formed using experiences around the world. This will increase the quality of the existing urban forests and the recognition of the urban forests by the society. In addition, there is need for public relations to increase the number of visitors to urban forests.

This study has found that number of population, urbanization ratio and forest area per capita have no effect on the establishment of urban forests. In fact, these characteristics have to be taken into consideration in deciding on the establishment of urban forests and the selection of their locations. In addition, they guide the planner in many technical topics, such as defining the size of urban forests and the capacity of their facilities. Consequently, these characteristics should be considered in establishing the urban forests.

Some of the studied 52 urban forests were rather distant from urban settlements and only half of them were within walking distance. Moreover, the majority of urban forests can not been reached by public transport. However, easy access is one of the most important drivers for a city-dweller to adapt to urban forests and to increase their use. For these reasons, proximity of urban forests to the city and reachability by walking or public transport are important.

According to the recreation regulation of Turkey, the established urban forests should also have included purposes other than recreation. Yet, it was determined that the majority of urban forests in Turkey were used only for meeting the picnic and entertainment need of visitors. Besides these purposes, urban forests should be established to reduce carbon emission, to mitigate air pollution, to present social functions such as education, health, sport, aesthetic and culture to public, to introduce technical forestry activities and to give information about flora and fauna in urban forests.

The majority of urban forests in Turkey have no lake-pond or stream. The value of a recreation area increases with the presence of lake-pond or streams apart from plant and animal diversity. The demand of the society for urban forests will increase if water bodies such as a lake-pond or stream are available in urban forests.

Almost all urban forests had no management plan and the number of their managerial and technical personal was low. This is evidence that urban forests were not managed based on scientific and technical principles. However, the urban forests that have a management plan and enough managerial and technical personal can provide experience for formulating regulations. Therefore, management plans should be provided for each urban forest.

Service units in most urban forests have not been fulfilled, yet. Prominent facilities provided in urban forests were walking paths and playgrounds. Half of urban forests have no parking area and an information center. Actually, service units determining the visitor demand in urban forests have to be completed. Also recreational capacity definitely should be taken into account in the establishment of above mentioned units.

The number of tree and animal species in urban forests was low as inventory works for them were not done sufficiently. After inventory works are conducted in actual urban forests information points and signs have to be introduced for tree and other species. Moreover, tree species, plant and animal diversity should be considered in prospective urban forests.

Deficiencies in the legal and administrative infrastructure of urban forests in Turkey were not limited to the results of the present study only. All deficiencies of urban forest management need to be assessed by various scientific researchers. When following a participatory approach urban forests could serve the society more effectively. Finally, there is need for scientific studies to show legal and administrative aspects of urban forests.

\section{Acknowledgements}

The help of the General Directorate of Forestry (OGM) personnel during the data collection is very much appreciated, and we would like to give special thanks to Fethi ARSLAN, director of the OGM Education Department. 


\section{REFERENCES}

1. KUCHELMEISTER G, BRAATZ S 1993 Urban forestry revisited. Unasylva 173 (44): 3-12

2. ATMIŞ E 2004 Ormanlar Üzerindeki Kent Kökenli Baskılar ve Kentli Duyarlılığı (Urban Pressures and Urban Sensitivity on Forests). In: $1^{\text {st }}$ National Urban Forestry Congress Proceedings Book, Ankara, pp 401-413

3. ATMIŞ E, ÖZDEN S, LISE W 2007 Urbanization pressures on the natural forests in Turkey: an overview. Urban For Urban Gree 6 (2): 83-92

4. OGM 2012 T.C. Orman Genel Müdürlüğü, Odun Dışı Ürün ve Hizmetler Dairesi Başkanlığı, Mesire Yerleri Şube Müdürlüğü Kayıtları. (General Directorate of Forestry, Report of Nonwood Products and Services Department) Available at: http://web.ogm.gov.tr/birimler/merkez/ odundisiurun/Dkmanlar/Mesire\%20Yerleri\%20 Sube\%20Mudurlugu/Kent\%200rmanlar\%C4\%B1.pdf (Accessed: 21 December 2012)

5. KONIJNENDIJK C C 2003 A decade of urban forestry in Europe. Forest Policy Econ 5: 173-186

6. TYRVÄINEN L 1997 The amenity value of the urban forest: an application of the hedonic pricing method. Landscape Urban Plan 37: 211-222

7. JORGENSEN E 1986 Urban forestry in the rearview mirror. Arboricultural Journal 10: 177-190

8. KONIJNENDIJK C C, RICARD R M, KENNEY A, RANDRUP T B 2006 Defining urban forestry - A comparative perspective of North America and Europe. Urban For Urban Gree 4 (3-4): 93-103

9. JIM C Y, CHEN W Y 2009 Ecosystem services and valuation of urban forest in China. Cities 26: 187-194

10. KONIJNENDIJK C C 2008 The forest and city - The cultural landscape of urban woodland. Springer, Berlin, p 245

11. YILMAZ S, BULUT Z, YEŞIL P 2006 The benefits of urban forests to urban space. Ataturk University Journal of Agriculture Faculty 37 (1): 131-136

12. GEZER A, GÜL A 2009 Kent ormancılığı - Kavramsal, teknik ve kültürel yaklaşımlar (Urban forestry - Conceptual, technical and cultural approaches). Süleyman Demirel University Forestry Faculty Publications, Isparta-TURKEY, p 244

13. COŞKUN A A, VELIOĞLU N 2004 Kent Ormanı Tanımı ve Hukuksal Boyutu (Definition and Legal Aspect of Urban Forest). In: $1^{\text {st }}$ National Urban Forestry Congress Proceedings Book, Ankara, pp 19-33

14. ELVAN D, VELIOĞLU N 2004 Kent Ormanı Yönetiminin Yasal Esasları (Legal Principals of Urban Forest Management). In: $1^{\text {st }}$ National Urban Forestry Congress Proceedings Book, Ankara, pp 118-133
15. OĞUZ D 2004 Avrupa Ülkelerinde Kent Ormancılığı Araştırmaları (Research of Urban Forestry in Europe Countries). In: $1^{\text {st }}$ National Urban Forestry Congress Proceedings Book, Ankara, pp 223-236

16. ÇAKCI I, ÇELEM H 2004 Gelişmekte Olan Ülkelerde Kentsel Yaşam Kalitesinin Artırılmasında Çok Amaçlı Kent Ormancılığı Uygulamaları (Multipurpose Urban Forestry Applications in Developing Countries to enhance Urban Life Quality). In: $1^{\text {st }}$ National Urban Forestry Congress Proceedings Book, Ankara, pp 237-249

17. ÇAĞLAR Y 2004 Türkiye Ormancılığı'nın Yeni Serüveni: "Kent Ormancılığı" (New Adventure of Forestry in Turkey: "Urban Forestry"). In: $1^{\text {st }}$ National Urban Forestry Congress Proceedings Book, Ankara, pp 472-481

18. REGA 2012 T.C. Resmi Gazetesi, Mesire Yerleri Yönetmeliği, (Picnic Spots Regulations in Official Gazette) Resmi Gazete Tarihi: 30.09.2006 Resmi Gazete Sayısı: 26305.

19. ZHU P, ZHANG Y 2008 Demand for Urban Forests in United States Cities. Landscape Urban Plan 84: 293-300

20. KUCHELMEISTER G 1998 Urban Forestry: Present Situation and Prospects in the Asia and Pasific region, FAO Asia-Pasific Forestry Sector Outlook Study, FAO Working Paper No: APFSOS/WP/44, Food and Agriculture Organization of the United Nations, Rome.

21. SINGH V S, PANDEY D N, CHAUDHRY P 2010 Urban forests and open green spaces: Lessons for Jaipur, Rajasthan, India. Rajasthan State Pollution Control Board, Rajasthan, India, p 22

22. ASLAN Z 1993 Sanayileşme ve kentleşmenin doğada rekreasyon faaliyetlerine duyulan gereksinimi arttırıcı etkisi (The Increasing Effect of Industrialization and Urbanization on the Recreation Activities Need in the Nature). Ekoloji Dergisi 8: 22-24

23. HÖRNSTEN L, FREDMAN P 2000 On the distance to recreational forests in Sweden. Landscape Urban Plan 51(1): 1-10

24. ROOVERS P, HERMY M, GULINCK H 2002 Visitor profile, perceptions and expectations in forests from a gradient of increasing urbanization in central Belgium. Landscape Urban Plan 59:129-145

25. SCHIPPERIJN J, STIGSDOTTER $U$ K, RANDRUP $T$ B, TROELSEN J 2010 Influences on the use of urban green space - A case study in Odense, Denmark. Urban For Urban Gree 9 (1): 25-32

26. KONIJNENDIJK C C 2002 Urban Woodland Conservation, Management and Development in Europe - A Comparative Study. In: Randrup T B, Konijnendijk C C, Christophersen T, Nilsson K (eds) Urban Forests and Trees - Proceedings No 1. COST Action E12. Office for Official Publications of the European Communities, Luxembourg, pp 163-180 
27. COLES R W, BUSSEY S C 2000 Urban forest landscapes in the UK-progressing the social agenda. Landscape Urban Plan 52: 181-188

28. TYRVÄINEN L, PAULEIT S, SEELAND K, DE VRIES S 2004 Benefits and Uses of Urban Forests and Trees. In: Nilsson K, Randrup T B, Konijnendijk C C (eds) Urban Forests and Trees in Europe A Reference Book. Springer Verlag (in print), p 24

29. USLU Ş, AYAŞLIGIL T 2007 Kent ormanlarının rekreasyonel amaçlı kullanımı ve İstanbul ili örneğinde irdelenmesi (Recreational usage of urban forests and a scrutiny of the Istanbul case). YTÜ Arch. Fac. E-Journal 2 (4): 213236

30. SCHMITHÜSEN F, KAZEMI Y, SEELAND K 1997 Perceptions and attitudes of the population towards forests and their social benefits. Social origins and research topics of studies conducted in Germany, Austria and Switzerland between 1960 and 1995. IUFRO Occasional Paper 7. IUFRO, Vienna

31. TYRVÄINEN L, SILVENNOINEN $H$, KOLEHMAINEN O 2003 Can ecological and aesthetic values be combined in urban forest management? Urban For Urban Gree 1(3):135-149
32. ÇETINER Ş, KIRIŞ R, YILMAZ A 2004 Kent Ormancılığında Hukuki ve Teknik Altyapı (Legal and Technical Infrastructure of Urban Forestry). In: $1^{\text {st }}$ National Urban Forestry Congress Proceedings Book, Ankara, pp 96-117

33. CLARK J R, MATHENY N P, CROSS G, WAKE V 1997 A model of urban forest sustainability. Journal of Arboriculture 23 (1):17-30

34. NOWAK D J, HOEHN III R E, CRANE D E, STEVENS J C, WALTON J T, BOND N Y J, INA G 2006 Assessing urban forest effects and values. USDA Forest Service Publications, Northeastern Research Station Resource Bulletin NE-166, p 5

35. DIRIK H, ATA C 2004 Kent Ormancılığının Kapsamı, Yararları, Planlaması ve Teknik Esasları (Scope, Benefits, Planning and Technical Principles of Urban Forestry). In: $1^{\text {st }}$ National Urban Forestry Congress Proceedings Book, Ankara, pp 63-77

36. RINES D, KANE $B$, KITTREDGEA D B, RYANA H D P, BUTLERA B 2011 Measuring urban forestry performance and demographic associations in Massachusetts, USA. Urban For Urban Gree 10 (2): 113-118 